Article

\title{
Catechol-Type Flavonoids from the Branches of Elaeagnus glabra f. oxyphylla Exert Antioxidant Activity and an Inhibitory Effect on Amyloid- $\beta$ Aggregation
}

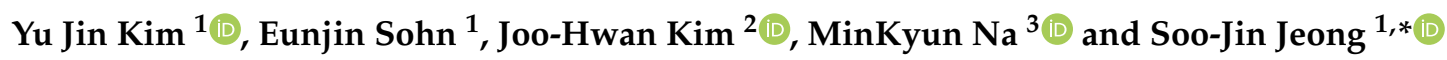 \\ 1 Clinical Medicine Division, Korea Institute of Oriental Medicine, Daejeon 34054, Korea; \\ jinjin0228@kiom.re.kr (Y.J.K.); ssen4022@kiom.re.kr (E.S.) \\ 2 Department of Life Science, Gachon University, Seongnam, Gyeonggi-do 13120, Korea; \\ kimjh2009@gachon.ac.kr \\ 3 College of Pharmacy, Chungnam National University, Daejeon 34134, Korea; mkna@cnu.ac.kr \\ * Correspondence: sjijeong@kiom.re.kr; Tel.: +82-42-868-9651
}

Received: 9 September 2020; Accepted: 21 October 2020; Published: 23 October 2020

\begin{abstract}
Elaeagnus glabra f. oxyphylla (Elaeagnaceae) is a small evergreen tree with narrow lanceolate leaves that is native to Korea. In this work, we studied the chemical composition of E. glabra $\mathrm{f}$. oxyphylla branches (EGFOB) for the first time. Additionally, we evaluated the effects of the ethanol extract of EGFOB and each of its chemical components on key mediators of Alzheimer's disease $(\mathrm{AD})$, namely, amyloid- $\beta(\mathrm{A} \beta)$ aggregation and oxidative stress. The ethanol extract of EGFOB decreased $A \beta$ aggregation $\left(\mathrm{IC}_{50}=32.01 \mu \mathrm{g} / \mathrm{mL}\right.$ ) and the levels of the oxidative free radicals 2,2'-azino-bis(3-ethylbenzothiazoline-6-sulphonic acid) (ABTS) and 2,2-diphenyl-1-picrylhydrazyl $(\mathrm{DPPH})\left(\mathrm{IC}_{50}=11.35\right.$ and $12.32 \mu \mathrm{g} / \mathrm{mL}$, respectively). Sixteen compounds were isolated from EGFOB. Among them, procyanidin B3 (8), procyanidin B4 (9), and helichrysoside (13) significantly inhibited $\mathrm{A} \beta$ aggregation ( $\mathrm{IC}_{50}=14.59,32.64$, and $44.45 \mu \mathrm{M}$, respectively), indicating their potential as bioactive compounds to control $A \beta$ aggregation. Furthermore, these compounds markedly enhanced in vitro scavenging activity against ABTS $\left(\mathrm{IC}_{50}=3.21-4.61 \mu \mathrm{M}\right)$. In the DPPH test, they showed lower scavenging activity than in the ABTS test $\left(\mathrm{IC}_{50} \geq 54.88 \mu \mathrm{M}\right)$. Thus, these results suggest that EGFOB and specifically compounds $\mathbf{8}, \mathbf{9}$, and $\mathbf{1 3}$ may be beneficial in $\mathrm{AD}$ prevention and treatment through their antioxidant and anti-A $\beta$ aggregation activities.
\end{abstract}

Keywords: Elaeagnus glabra f. oxyphylla; Elaeagnaceae; amyloid- $\beta$; antioxidant; flavonoid

\section{Introduction}

Alzheimer's disease (AD) is a progressive neurodegenerative disorder with no available cure. The incidence rate is higher among people over the age of 60 , with $\mathrm{AD}$ patients accounting for $60-80 \%$ of all dementia cases [1,2]. Currently, the number of dementia patients in the world is estimated at 44 million, and this number is predicted to more than triple by 2050 [3].

$\mathrm{AD}$ is characterized by cognitive disruptions, such as memory loss and language difficulties, and non-cognitive dysfunctions, such as behavioral disturbance, depression, hallucination, and delusion $[4,5]$. The hallmark of $A D$ pathogenesis is the progressive accumulation of amyloid- $\beta(A \beta)$ in the brain [6]. $A \beta$ plaques are extracellular accumulations of pathological forms of $A \beta$ that are principally composed of abnormally folded $A \beta$, such as $A \beta_{1-40}$ and $A \beta_{1-42}$. Because of its higher rates of fibrillation and insolubility, $A \beta_{1-42}$ is more abundant in the plaques than $A \beta_{1-40}$ [3]. $A \beta$ aggregation can be initiated by oxidative stress in the early stage of $A D$, and $A \beta$ plaques also influence free radical 
generation and oxidative stress [7-9]. The excessive generation of free radicals in pathological AD conditions causes an imbalance between free radicals and antioxidants, which are conditions for oxidative stress [9]. Furthermore, previous studies have indicated that $A \beta_{1-42}$ is neurotoxic. It increases the oxidation of proteins in the cell, thereby leading to neuronal dysfunction and cell death during the late stage of $\mathrm{AD}$ [10]. The neurotoxicity of abnormal $\mathrm{A} \beta$ deposition results from oxidative stress, which is central in the neuronal cell death and inflammation associated with the pathogenesis of $\mathrm{AD}$ [11]. It has been reported that antioxidants can attenuate the symptoms of $\mathrm{AD}$ and prevent progression [7]. Therefore, new $\mathrm{AD}$ drugs that target $\mathrm{A} \beta$ with potent antioxidant activity may be useful in the prevention and treatment of AD.

Unfortunately, there is currently no cure for $\mathrm{AD}$, and the current treatment strategies are aimed at symptom relief rather than correction of the underlying cause. There are two classes of medications approved for AD by the US Food and Drug Administration, namely, cholinesterase inhibitors (ChEIs) (donepezil, rivastigmine, and galantamine) and the $N$-methyl-D-aspartate (NMDA) receptor antagonist memantine [9]. These drugs temporarily alleviate symptoms, thereby improving patients' quality of life, but there is no evidence that they suppress AD progression. In addition, the administration of these drugs has been reported to cause side effects, such as leg cramps, flatulence, and increased gastrointestinal secretions for ChEIs, and confusion, dizziness, constipation, and headache for NMDA receptor antagonists $[3,12]$. In contrast, most natural products have lower toxicity and fewer side effects $[13,14]$ and thus represent attractive therapeutic candidates.

Elaeagnus glabra f. oxyphylla (Servett.) W. T. Lee (Elaeagnaceae) is a small evergreen tree with narrower lanceolate leaves than those of E. glabra [15]. This plant species is native to Korea (Jeju) and is also distributed in China. Several studies have described the pharmacological effects and phytochemicals of plants belonging to the genus Elaeagnus. It has been reported that E. glabra has anti-tumor and antibacterial effects, and it has been used to treat tetanus, asthma, and diarrhea [16,17]. E. angustifolia exerts antinociceptive, anti-inflammatory, antimicrobial, antioxidant, and antimutagenic activities [18,19]. E. umbellate is known to have antidiabetic, antioxidant, and anticancer properties [20,21]. Interestingly, our previous study reported the memory-ameliorating effects of E. glabra f. oxyphylla in a mouse model of scopolamine-induced memory impairment [22]. Previous studies have reported that the genus Elaeagnus contains flavonoids, triterpenoids, lignan glycosides, and phenolic compounds [17,20,23]. However, there have been no phytochemical studies using E. glabra f. oxyphylla extracts.

Since the neuronal $\mathrm{A} \beta$ aggregation in $\mathrm{AD}$ occurs early during the pathogenesis and appears to be the main pathogenic cause [6], blocking $A \beta$ accumulation may suppress the progression of AD [24]. Therefore, in the present study, we assessed ethanol extracts of E. glabra f. oxyphylla branches (EGFOB) and leaves (EGFOL) and their chemical components for their inhibitory effects on $A \beta$ aggregation.

\section{Results and Discussion}

\subsection{Inhibitory Effects of EGFOB and EGFOL on A Aggregation}

To explore whether E. glabra f. oxyphylla has an inhibitory effect on $A \beta$ aggregation, we prepared ethanol extracts of EGFOB and EGFOL at various concentrations $(6.25,12.5,25,50$, or $100 \mu \mathrm{g} / \mathrm{mL})$. Both EGFOB and EGFOL extracts inhibited in vitro $A \beta$ aggregation in a dose-dependent manner $\left(\mathrm{IC}_{50}=32.01\right.$ and $92.97 \mu \mathrm{g} / \mathrm{mL}$, respectively) (Figure 1A, B). These results indicate that EGFOB have a stronger inhibitory effect on $A \beta$ aggregation compared with EGFOL. $A \beta$ aggregation is one of the primary pathological indicators in AD patients [6]. Despite continuous debate about the relevance of $\mathrm{A} \beta$ as a target biomarker in new drug development for $\mathrm{AD}$, many researchers are still focusing on $A \beta$ [25-27]. The amyloid hypothesis suggests that the abnormality of $A \beta$ is observed somewhat earlier before the onset of $\mathrm{AD}$ compared with other $\mathrm{AD}$ biomarkers [28]. Therefore, $\mathrm{A} \beta$ should be considered an important priority in investigations for the prevention as well as the treatment of $\mathrm{AD}$. In our study, the robust activity of EGFOB is a notable result for anti-A $\beta$ therapy research. 
(A)

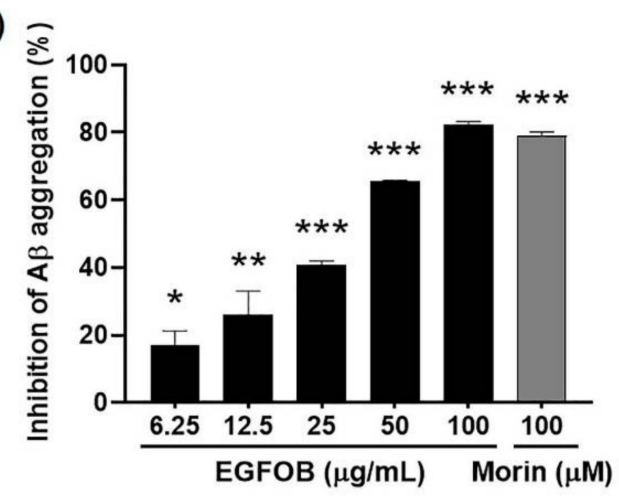

(B)

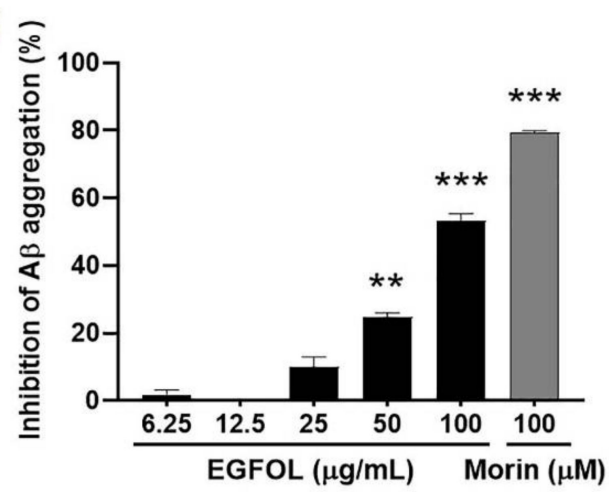

Figure 1. Inhibitory effects of E. glabra f. oxyphylla branches (EGFOB) and leaves (EGFOL) extracts on amyloid- $\beta$ (A $\beta$ ) aggregation. Various concentrations $(6.25,12.5,25,50$, or $100 \mu \mathrm{g} / \mathrm{mL})$ of (A) EGFOB and (B) EGFOL were prepared and reacted with $\mathrm{A} \beta_{1-42}$ peptides, followed by the addition of Thioflavin (ThT). Fluorescence intensity was measured at $440 \mathrm{~nm}$ (excitation) and $485 \mathrm{~nm}$ (emission). Each value is expressed as the mean $\pm \operatorname{SEM}(n=3) .{ }^{*} p<0.05,{ }^{* *} p<0.01$, or ${ }^{* * *} p<0.001$ vs. control.

\subsection{Antioxidant Effects of EGFOB and EGFOL}

Oxidative stress induced by $A \beta$ in the brain is related to the pathogenesis of AD [11]. Previous studies have reported that many natural products have robust antioxidant properties $[29,30]$. To examine the antioxidant activities of EGFOB and EGFOL, 2,2'-azino-bis(3-ethylbenzothiazoline-6-sulphonic acid) (ABTS) and 2,2-diphenyl-1-picrylhydrazyl (DPPH) radical scavenging assays, widely used to assess the antioxidant efficacy of natural products $[29,30]$, were performed. The EGFOB and EGFOL extracts reached $100 \%$ ABTS radical scavenging activity at the concentrations of 25 and $100 \mu \mathrm{g} / \mathrm{mL}$, respectively $\left(\mathrm{IC}_{50}=11.35\right.$ and $26.01 \mu \mathrm{g} / \mathrm{mL}$, respectively) (Figure $2 \mathrm{~A}, \mathrm{~B}$ ). While the EGFOB extract showed similar results in the DPPH assay to those in the ABTS assay, the EGFOL extract had a significant effect on DPPH radical scavenging only at $100 \mu \mathrm{g} / \mathrm{mL}\left(\mathrm{IC}_{50}=12.32\right.$ and $>100 \mu \mathrm{g} / \mathrm{mL}$, respectively) (Figure 2C,D). The remarkable radical scavenging activity of EGFOB extract against ABTS and DPPH indicates the antioxidant capacity of EGFOB. Previous studies have been reported focusing on the relationship between free radicals and the formation of $A \beta$ aggregates in AD development. $\mathrm{A} \beta$ plaques contributes to the generation of free radicals and oxidative stress [31], and it was found that oxidative stress is closely related to $A \beta$ aggregation [32]. As is well known, there are many natural products that are powerful antioxidants and can play an important role in the regulation of various chronic diseases, including $\mathrm{AD}$. In new drug development for AD, natural extracts such as EGFOB are attractive agents with dual- or multi-function. By comparing the effects of the two extracts in the $A \beta$ aggregation and radical scavenging assays according to the $\mathrm{IC}_{50}$ values, it was found that the EGFOB extract was more effective than the EGFOL extract.

\subsection{Inhibitory Effects of the Solvent Fractions of EGFOB on A Aggregation}

The ethanol extract of EGFOB was suspended in water and successively fractionated by using $n$-hexane, ethyl acetate (EtOAc), and $n$-butanol $(n$-BuOH) (Figure 3). The $\mathrm{A} \beta$ aggregation assay was performed using the water, $n$-hexane, EtOAc, and $n-\mathrm{BuOH}$ fractions. As shown in Figure 4 , the EtOAcand $n-\mathrm{BuOH}$-soluble fractions significantly inhibited $\mathrm{A} \beta$ aggregation $\left(\mathrm{IC}_{50}=24.31\right.$ and $30.24 \mu \mathrm{g} / \mathrm{mL}$, respectively), unlike the other fractions. This observation indicates that the EtOAc- and $n$-BuOH-soluble fractions contain the bioactive compounds of EGFOB against $A \beta$ aggregation. 
(A)

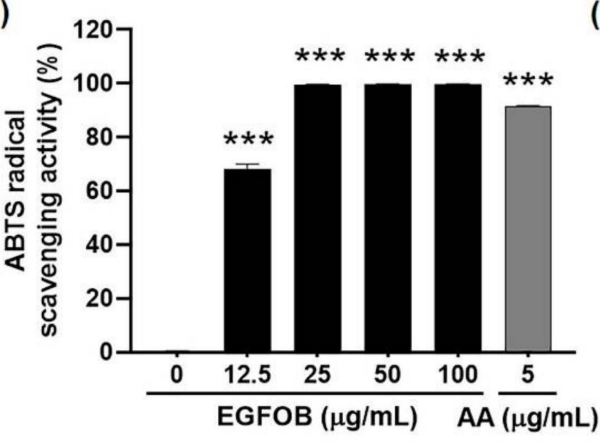

(B)

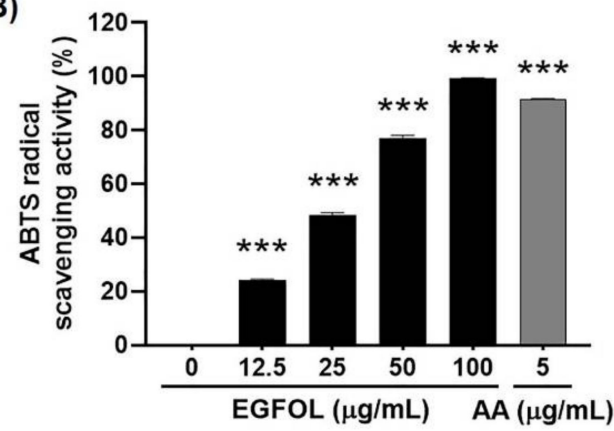

(C)

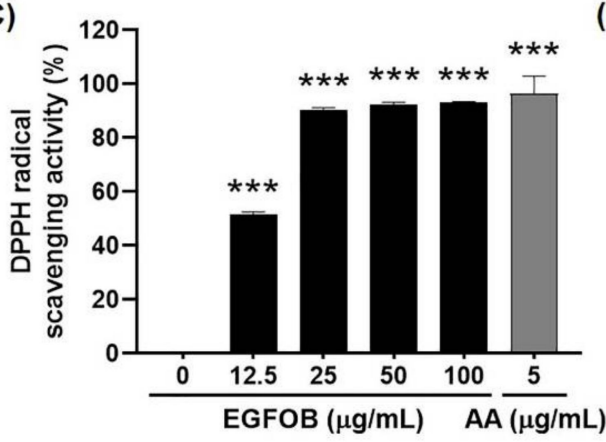

(D)

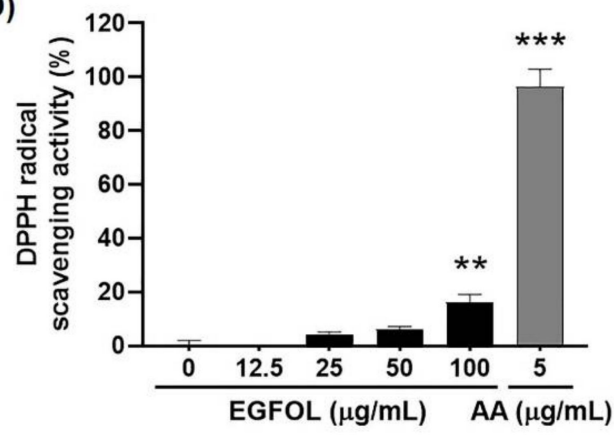

Figure 2. Antioxidant effects of E. glabra f. oxyphylla branches (EGFOB) and leaves (EGFOL). Antioxidant activity was measured by free radical scavenging assay for 2,2'-azino-bis(3-ethylbenzothiazoline-6sulphonic acid) (ABTS) (A,B) and 2,2-diphenyl-1-picrylhydrazyl (DPPH) (C,D). Each value is presented as the mean $\pm \operatorname{SEM}(n=3)$. Ascorbic acid (AA) was used as a positive control. ${ }^{* *} p<0.01$ or ${ }^{* * *} p<0.001$ vs. control.

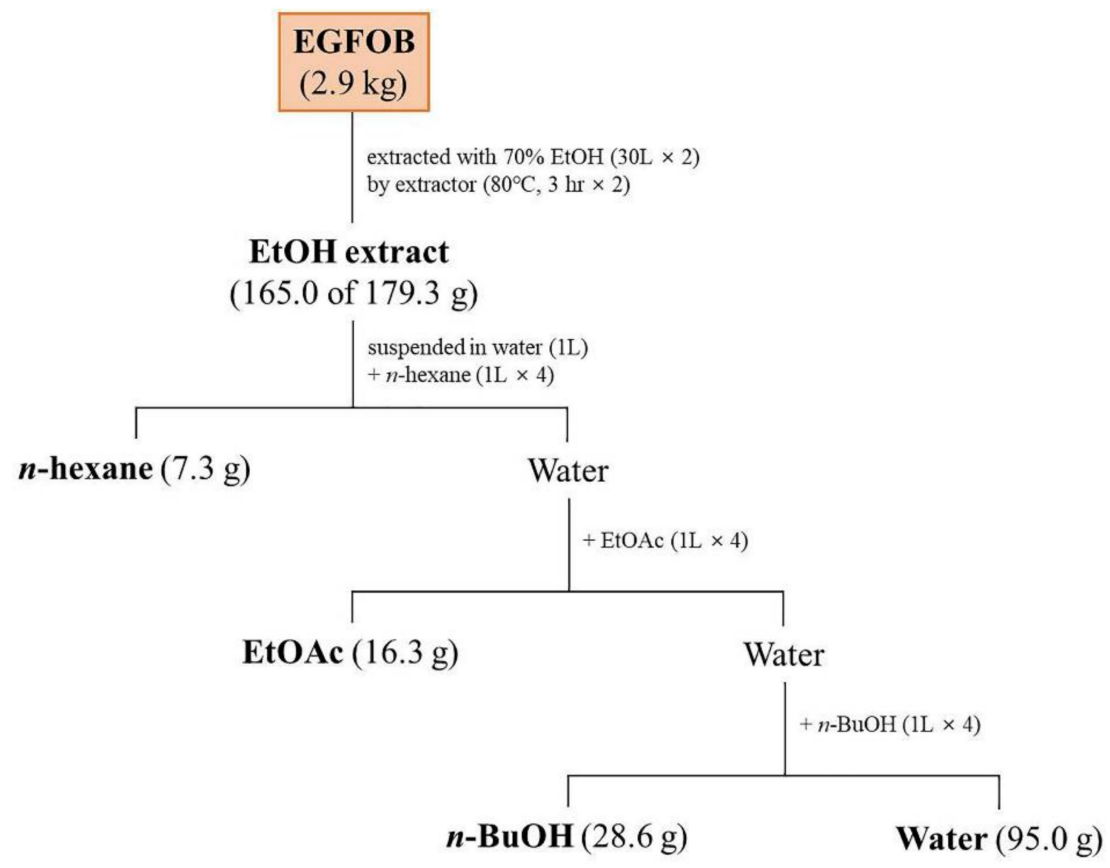

Figure 3. Extraction and fractionation of E. glabra f. oxyphylla branches (EGFOB). 
(A)

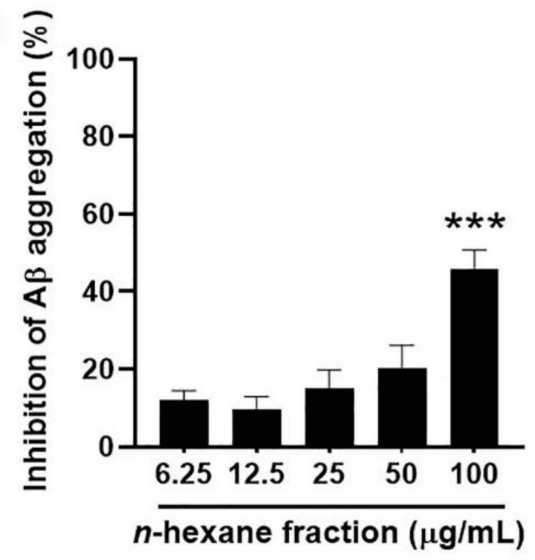

(C)

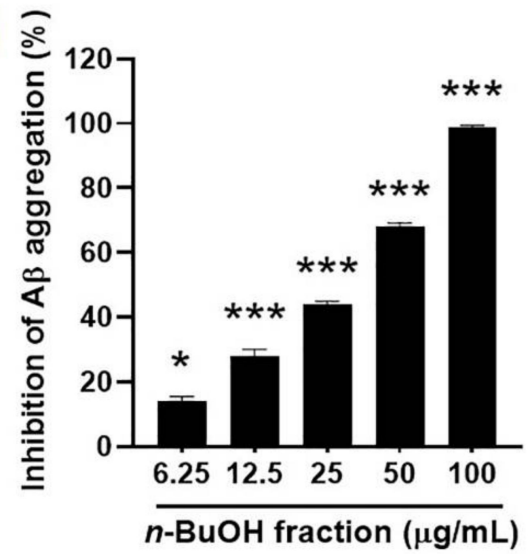

(B)

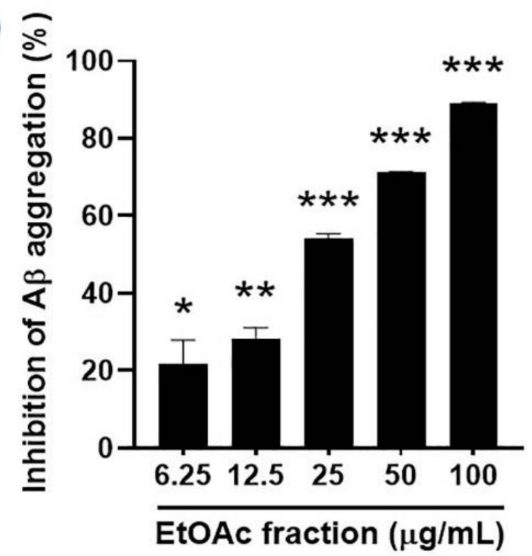

(D)

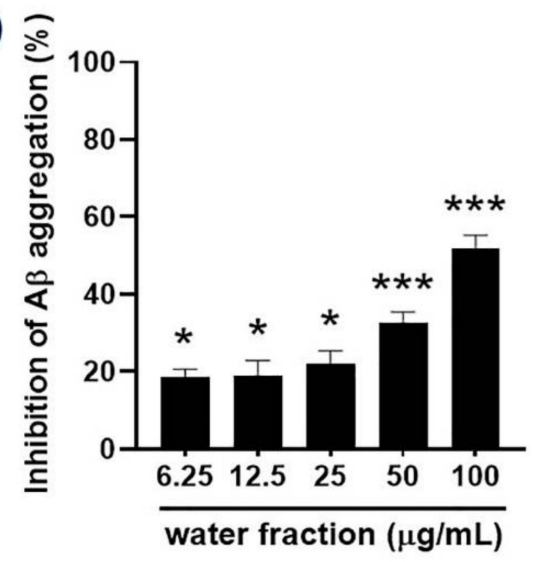

Figure 4. Inhibitory effects of solvent fractions of EGFOB on amyloid- $\beta(A \beta)$ aggregation. Various concentrations $(6.25,12.5,25,50$, or $100 \mu \mathrm{g} / \mathrm{mL})$ of (A) $n$-hexane, (B) EtOAc, (C) $n$-BuOH, and (D) water fractions were prepared and reacted with $A \beta_{1-42}$ peptides, followed by the addition of ThT. Fluorescence intensity was measured at $440 \mathrm{~nm}$ (excitation) and $485 \mathrm{~nm}$ (emission). Each value is expressed as the mean $\pm \operatorname{SEM}(n=3) .{ }^{*} p<0.05,{ }^{* *} p<0.01$, or ${ }^{* * *} p<0.001$ vs. control.

\subsection{Isolation and Identification of Compounds 1-16 from EGFOB}

To identify the chemical components that have antioxidative activities and inhibit $\mathrm{A} \beta$ aggregation, we isolated the chemical constituents from the EtOAc-soluble fraction of EGFOB, which significantly inhibited $\mathrm{A} \beta$ aggregation and had more components than $\mathrm{BuOH}$-soluble fraction according to the HPLC chromatogram (data not shown). We further fractionated the EtOAc-soluble fraction by using silica gel column chromatography to produce six subfractions (F1-F6). F1-F4 were further resolved using octadecylsilane (ODS) and Sephadex LH-20 column chromatography and preparative reversed-phase HPLC. Finally, sixteen compounds (1-16), including three phenols (1-3), ten flavonoids (4-13), two triterpenoids $(\mathbf{1 4}, \mathbf{1 5})$, and one fatty acid ester (16), were purified (Figure 5). By comparing the spectral and physicochemical properties of these compounds (Supplementary Materials) with those of previously reported compounds, the sixteen compounds were identified as 4-hydroxybenzoic acid (1) [33], salicylic acid (2) [34], vanillic acid (3) [35], (+)-catechin (4) [36], (-)-epicatechin (5) [37], (+)-gallocatechin (6) [36], (-)-epigallocatechin (7) [38], procyanidin B3 (8) [39], procyanidin B4 (9) [40], kaempferol (10) [41], astragalin (11) [42], trans-tiliroside (12) [38], helichrysoside (13) [43], betulinic acid-3-O-trans-caffeate (14) [44], ursolic acid-3-O-trans-caffeate (15) [45], and 1-mono(22-O-feruloyl-oxydocosanoyl)glycerol (16) [46]. Previous studies have reported the presence of various types of phytochemicals in the genus Elaeagnus, including flavonoids (e.g., rutin, epigallocatechin gallate, and isorhamnetin) and phenolic compounds (e.g., chlorogenic acid, pyrogallol, 
and ferulic acid) from E. umbellata [20], E. angustifolia [47], and E. pungens [48]; and triterpenoid saponins (e.g., terpengustifol), lignan glycosides (e.g., phengustifols A and B), and alkaloids (e.g., harmane and tetrahydroharmol) from E. angustifolia $[23,47]$. Of note, this study represents for the first time these sixteen compounds have been identified in EGFOB.<smiles>COc1cc(C(=O)O)ccc1O</smiles><smiles>Oc1cc(O)c2c(c1)OC(O)C(c1cc(O)c(O)c(O)c1)O2</smiles><smiles>Oc1cc(O)c2c(c1)O[C@H](c1cc(O)c(O)c(O)c1)[C@H](O)C2</smiles>

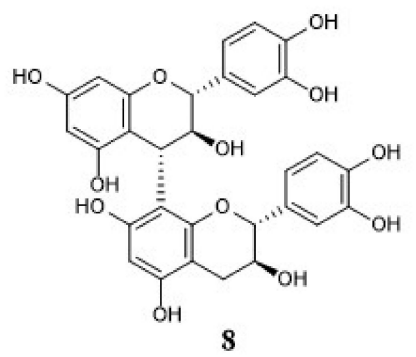<smiles>Oc1cc(O)c2c(c1)O[C@H](c1ccc(O)c(O)c1)[C@H](O)[C@H]2c1c(O)cc(O)c2c1O[C@H](c1ccc(O)c(O)c1)[C@H](O)C2</smiles><smiles></smiles>

10<smiles>O=c1c(OC2OC(CO)C(O)C(O)[C@@H]2O)c(-c2ccc(O)cc2)oc2cc(O)cc(O)c12</smiles>

11<smiles>O=C(/C=C/c1ccc(O)cc1)OCC1OC(Oc2c(-c3ccc(O)cc3)oc3cc(O)cc(O)c3c2=O)[C@H](O)[C@H](O)[C@H]1O</smiles>

12

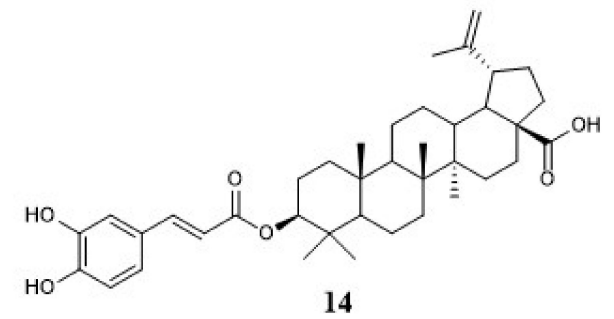<smiles>O=C(/C=C/c1ccc(O)cc1)OCC1OC(Oc2c(-c3ccc(O)c(O)c3)oc3cc(O)cc(O)c3c2=O)[C@H](O)C(O)[C@H]1O</smiles>

13

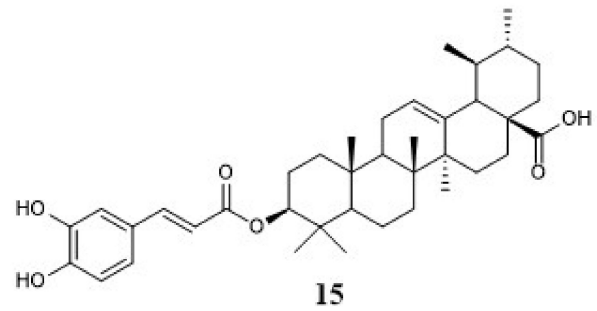<smiles>COc1cc(/C=C/C(=O)OCCCCCCCCCCCCCCCCCCCCCC(=O)OCC(O)CO)ccc1O</smiles>

Figure 5. Structures of compounds 1-16 constituting EGFOB. 4-hydroxybenzoic acid (1), salicylic acid (2), vanillic acid (3), (+)-catechin (4), (-)-epicatechin (5), (+)-gallocatechin (6), (-)-epigallocatechin (7), procyanidin B3 (8), procyanidin B4 (9), kaempferol (10), astragalin (11), trans-tiliroside (12), helichrysoside (13), betulinic acid-3-O-trans-caffeate (14), ursolic acid-3-O-trans-caffeate (15), and 1-mono(22-O-feruloyl-oxydocosanoyl)glycerol (16). 
The isolated compounds were simultaneously analyzed using HPLC. The sixteen compounds were successfully separated on a Luna Omega $C_{18}$ analytical column $(4.6 \times 250 \mathrm{~mm}, 5 \mu \mathrm{m}$, Phenomenex $)$ at $30{ }^{\circ} \mathrm{C}$ with two mobile phases consisting of $0.1 \%(v / v)$ aqueous trifluoroacetic acid (TFA) (a) and acetonitrile $(\mathrm{ACN})(\mathrm{b})$ within $60 \mathrm{~min}$. The conditions of the gradients were 10-15\% (b) for 0-15 $\mathrm{min}$, $15-50 \%$ (b) for $15-40 \mathrm{~min}, 50-100 \%$ (b) for $40-50 \mathrm{~min}$, and 100\% (b) for 50-60 min. The HPLC chromatograms of the ethanol extract of EGFOB and isolated compound mixture at $240 \mathrm{~nm}$ are presented in Figure 6.
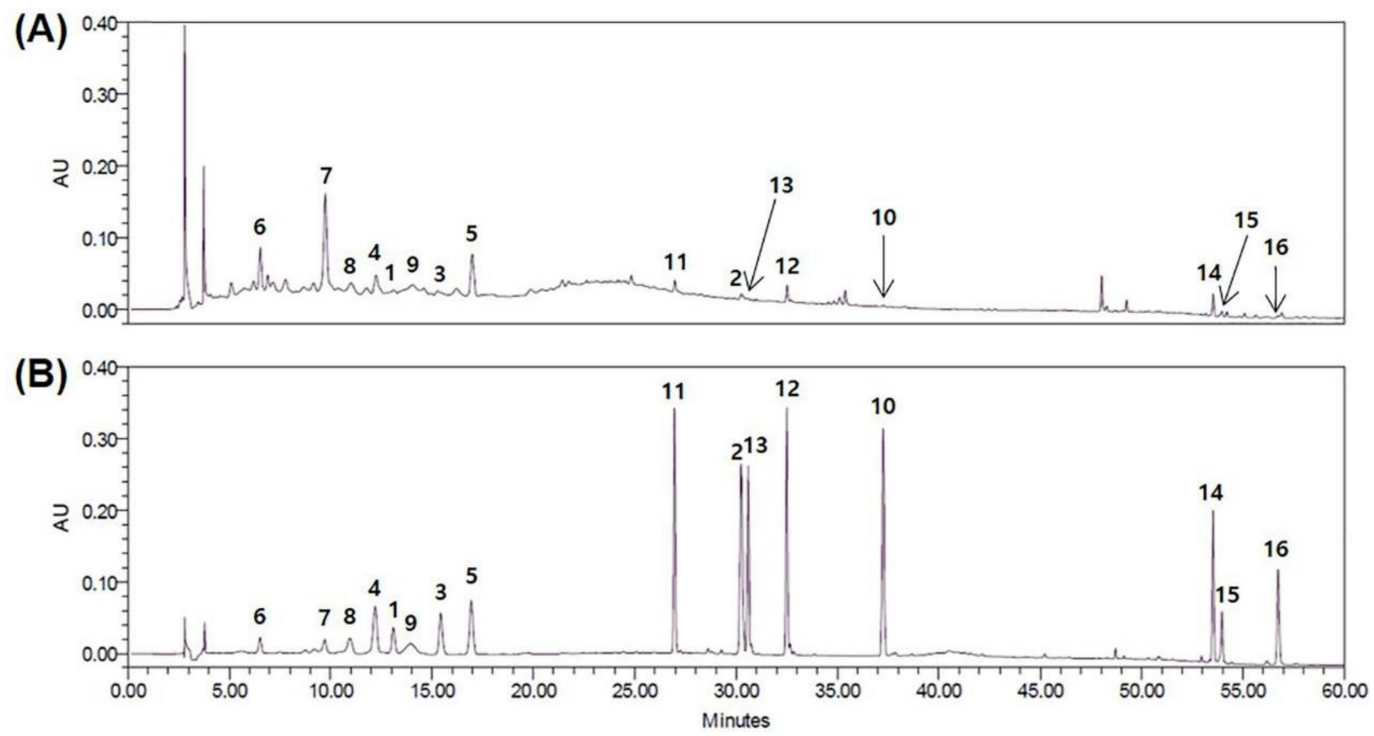

Figure 6. HPLC chromatograms of the ethanol extract of (A) EGFOB and (B) isolated compound mixture at $240 \mathrm{~nm}$.

\subsection{Inhibitory Effects of Compounds 1-16 from EGFOB on A $\beta$ Aggregation}

We evaluated the biological activities of the sixteen compounds through an in vitro $\mathrm{A} \beta$ aggregation assay and a free radical scavenging assay. Compounds 8, 9, and 13 inhibited $A \beta$ aggregation comparably to morin, a known inhibitor of $A \beta$ aggregation [49] (Figure 7A). Subsequently, we evaluated the inhibitory effects of these compounds on $A \beta$ aggregation at various concentrations $(6.25,12.5,25,50$, or $100 \mu \mathrm{M})$. Compounds 8, 9, and 13 significantly inhibited $\mathrm{A} \beta$ aggregation in a dose-dependent manner $\left(\mathrm{IC}_{50}=14.59,32.64\right.$, and $44.45 \mu \mathrm{M}$, respectively) (Figure 7B-D). These results indicate the potential of compounds $\mathbf{8}, \mathbf{9}$, and $\mathbf{1 3}$ as bioactive compounds to control $A \beta$ aggregation. The inhibitory rates of the other thirteen compounds were $<63 \%$.

It has been reported that phenolic compounds, including flavonoids, prevent oligomerization of $A \beta$ by changing its conformation [50]. Structure-activity relationship studies have revealed that the catechol moiety on ring $B$ of flavonoids plays a critical role in their inhibitory activities against $A \beta$ aggregation, and catechol-type flavonoids can specifically inhibit $A \beta_{1-42}$ aggregation by targeting lysine residues. In addition, flavonols containing a $\mathrm{C} 2-\mathrm{C} 3$ double bond on ring $\mathrm{C}$ have been found to inhibit $A \beta_{1-42}$ aggregation by reacting with the $\beta$-sheet regions of $A \beta_{1-42}$ aggregates $[51,52]$. These findings are in line with our observation that compounds 8 (catechin- $(4 \alpha \rightarrow 8)$-catechin dimer), 9 (catechin- $(4 \alpha \rightarrow 8)$-epicatechin dimer), and 13 (catechol-type flavonol) had stronger inhibitory effects on $A \beta$ aggregation than other compounds. 


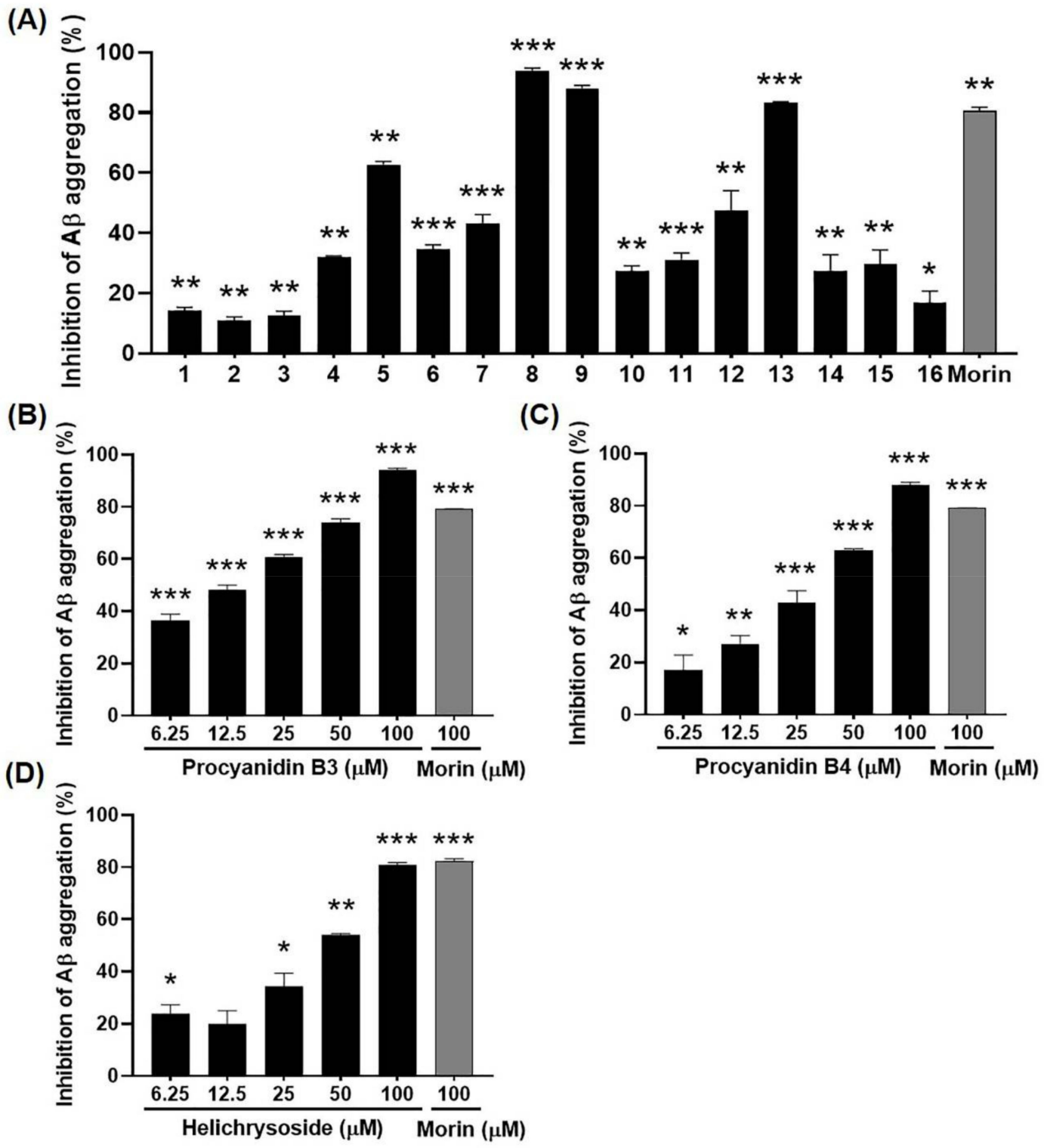

Figure 7. Inhibitory effects of compounds 1-16 from EGFOB on amyloid- $\beta(A \beta)$ aggregation. Compounds 1-16 $(100 \mu \mathrm{M})$ isolated from EGFOB (A) and various concentrations $(6.25,12.5,25,50$, or $100 \mu \mathrm{M})$ of procyanidin B3 (8) (B), procyanidin B4 (9) (C), and helichrysoside (13) (D) were reacted with A $\beta_{1-42}$ peptides, followed by the addition of ThT. Fluorescence was measured at $440 \mathrm{~nm}$ (excitation) and $485 \mathrm{~nm}$ (emission). Morin $(100 \mu \mathrm{M})$ was used as a positive control. Each value is shown as the mean \pm SEM $(n=3) .{ }^{*} p<0.05,{ }^{* *} p<0.01$, or ${ }^{* * *} p<0.001$ vs. control.

\subsection{Antioxidant Effects of Compounds 1-16 from EGFOB}

To examine the antioxidant activities of the sixteen compounds isolated from EGFOB, ABTS and DPPH radical scavenging assays were performed. Twelve compounds, excluding compounds 1, 2, 14, and 15, significantly increased radical scavenging activity against ABTS at $100 \mu \mathrm{M}$ (Figure 8A). The scavenging activities of compounds $1,2,14$, and 15 against ABTS were $<66 \%$. However, the DPPH radical scavenging activities of the sixteen compounds were $<56 \%$ (Figure $8 \mathrm{~B}$ ). Additionally, we evaluated the ABTS and DPPH radical scavenging activities of compounds 8,9 , and $\mathbf{1 3}$, candidate inhibitors of $A \beta$ aggregation, at various concentrations from 1.5625 to $100 \mu \mathrm{M}$. As shown in Figure $8 \mathrm{C}-\mathrm{E}$, compounds $8\left(\mathrm{IC}_{50}=3.21 \mu \mathrm{M}\right), \mathbf{9}\left(\mathrm{IC}_{50}=3.44 \mu \mathrm{M}\right)$, and $\mathbf{1 3}\left(\mathrm{IC}_{50}=4.61 \mu \mathrm{M}\right)$ dose-dependently enhanced radical scavenging activity against ABTS, which reached $100 \%$ at $12.5,12.5$, and $25 \mu \mathrm{M}$, respectively. In the DPPH test, we observed that the scavenging activity patterns of compounds $8, \mathbf{9}$, and $\mathbf{1 3}$ were 
similar to those detected in the ABTS test. However, the DPPH radical scavenging activities of these three compounds were $<52 \%\left(\mathrm{IC}_{50}=54.88,>100\right.$, and $>100 \mu \mathrm{M}$, respectively). As mentioned above, since $A \beta$ aggregation and free radicals are closely related, compounds 8, 9, and 13 targeting $A \beta$ with potent antioxidant activity are promising as valuable candidates for the prevention and treatment of AD. Additional studies will be necessary to identify the bioactive compounds of EGFOB in the inhibition of $\mathrm{AD}$ pathogenesis. In vitro and in vivo assays are required to determine the efficacy and safety of each candidate bioactive compound.

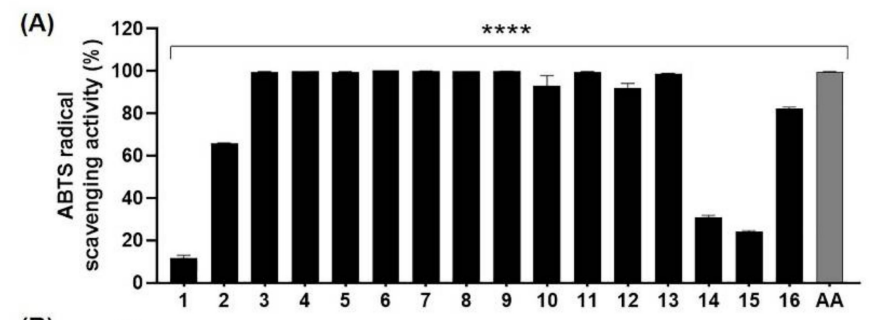

(B)

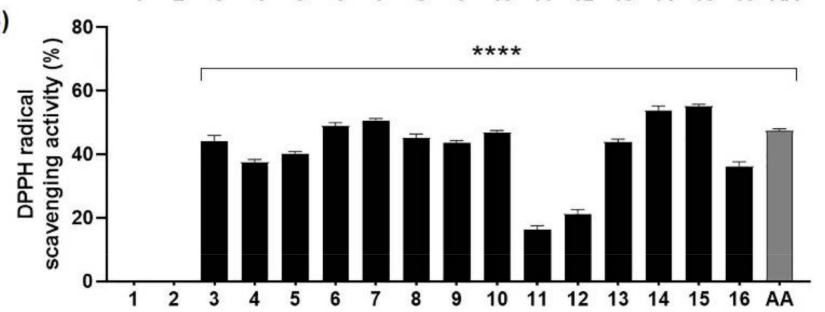

(C)
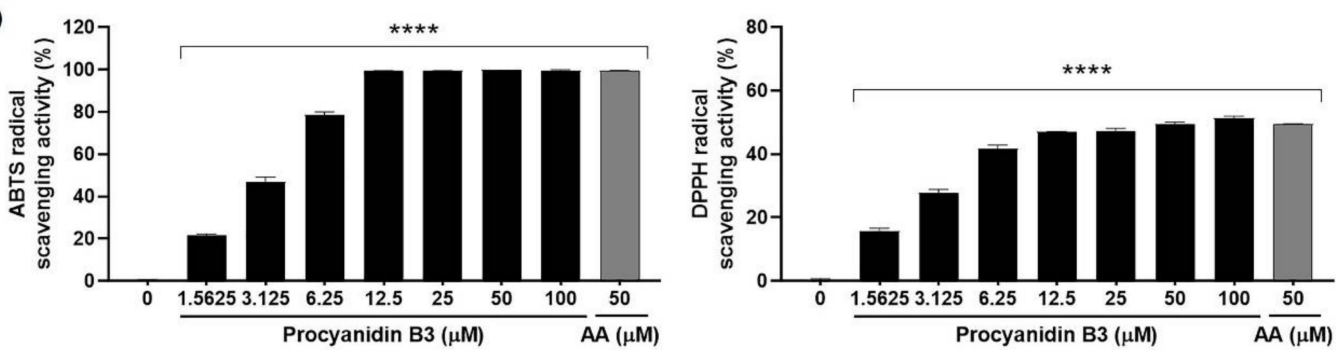

(D)
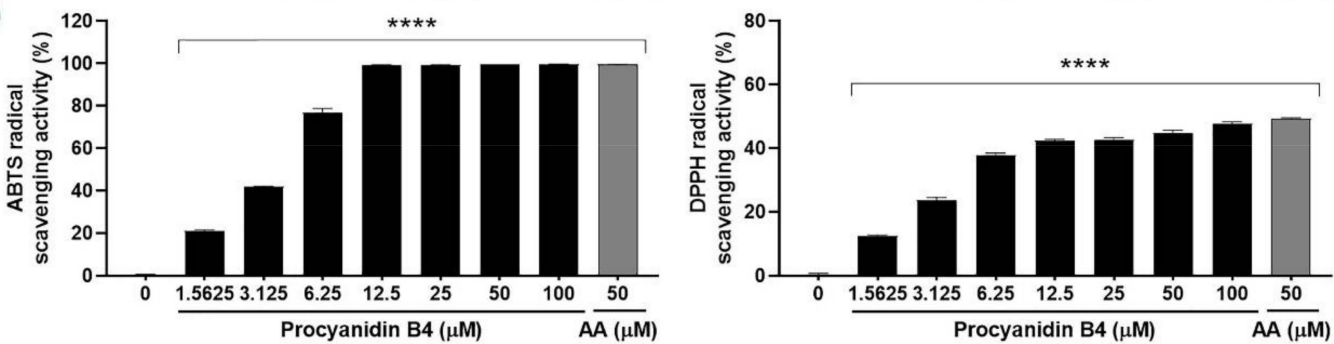

(E)
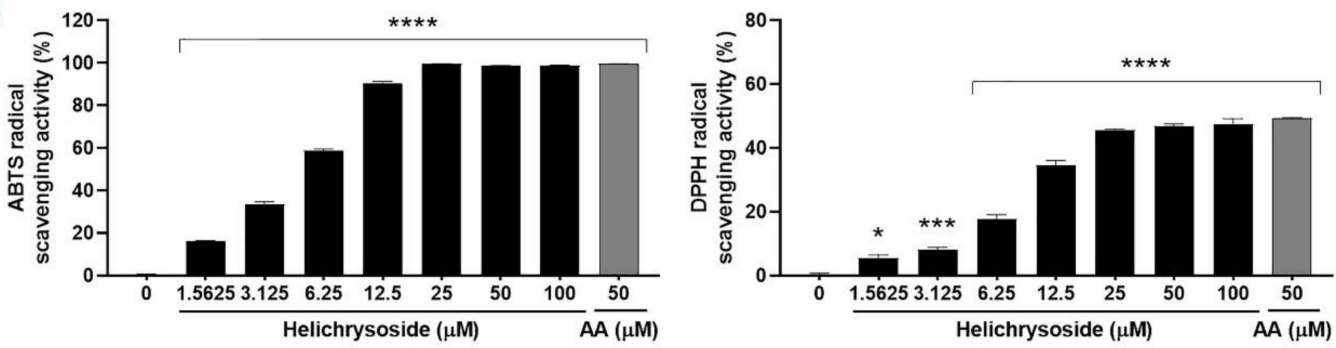

Figure 8. Antioxidant effects of compounds 1-16 from EGFOB. Antioxidant activities of compounds 1-16 (100 $\mu \mathrm{M})(\mathbf{A}, \mathbf{B})$, procyanidin B3 (8) (C), procyanidin B4 (9) (D), and helichrysoside (13) (E) $(1.5625-100 \mu \mathrm{M})$ were measured using ABTS and DPPH radical scavenging assays. Ascorbic acid (AA) $(50 \mu \mathrm{M})$ was used as a positive control. Each value is presented as the mean $\pm \operatorname{SEM}(n=3) .{ }^{*} p<0.05$, ${ }^{* * *} p<0.001$, or ${ }^{* * * *} p<0.0001$ vs. control. 


\section{Materials and Methods}

\subsection{General Experimental Procedures}

${ }^{1} \mathrm{H}-\mathrm{NMR}(500 \mathrm{MHz}),{ }^{13} \mathrm{C}-\mathrm{NMR}(125 \mathrm{MHz})$, and 2D NMR (HMQC, HMBC, and COSY) experiments were conducted on a Bruker Avance 500 NMR spectrometer (Bruker, Billerica, MA, USA). HRESI-MS and ESI-MS data were recorded on a SYNAPT G2 (Waters, Milford, MA, USA) mass spectrometer and Waters Acquity UPLC H-class system equipped with a QDa detector (Waters, Waters, Milford, MA, USA), respectively. Optical rotations were measured using the JASCO P-2000 digital polarimeter (JASCO, Tokyo, Japan). Infrared (IR) spectra were recorded on a Bruker ALPHA-T IR Spectrometer (Bruker, Billerica, MA, USA). Melting points were measured using a Mettler Toledo ${ }^{\mathrm{TM}}$ MP50 melting point apparatus (Mettler Toledo, Columbus, $\mathrm{OH}, \mathrm{USA}$ ). Column chromatography was performed using silica gel (70-230 mesh, Merck, Darmstadt, Germany), ODS-A (S-75 m, YMC Co., Ltd., Kyoto, Japan), and Sephadex ${ }^{\mathrm{TM}}$ LH-20 (GE Healthcare, Chicago, IL, USA). Preparative HPLC was performed on Luna $\mathrm{C}_{18}\left(21.2 \times 250 \mathrm{~mm}, 5 \mu \mathrm{m}\right.$, Phenomenex, Torrance, CA, USA), Triart $\mathrm{C}_{18}(20 \times 250 \mathrm{~mm}, 5 \mu \mathrm{m}, \mathrm{YMC}$ Co. Ltd., Kyoto, Japan), and Luna $C_{18}(10 \times 250 \mathrm{~mm}, 5 \mu \mathrm{m}$, Phenomenex, Torrance, CA, USA $)$ columns with analytical grade water and ACN (J. T. Baker Chemical Co., Phillipsburg, NJ, USA) as mobile phases by using the Interface LC 3000 system. Thin-layer chromatography was performed on $60 \mathrm{~F}_{254}$ or RP-18 $\mathrm{F}_{254}$ (Merck, Darmstadt, Germany) pre-coated with silica gel. To identify the isolated compounds from their HPLC chromatogram, HPLC was performed on a Luna Omega $C_{18}(4.6 \times 250 \mathrm{~mm}, 5 \mu \mathrm{m}$, Phenomenex, Torrance, CA, USA) analytical column by using a Waters Alliance e2695 system equipped with a photodiode array detector (\#2998, Waters, Milford, MA, USA). The analytical grade reagent TFA was purchased from Sigma-Aldrich (St. Louis, MO, USA).

\subsection{Plant Materials}

Dried EGFOB and ethanol extracts of EGFOL were obtained from the Korean Seed Association. The origins of the herbal materials were identified by Professor Joo-Hwan Kim (Gachon University, Seongnam, Korea). A voucher specimen (SCD-A-112) was deposited at the Clinical Medicine Division of Korea Institute of Oriental Medicine (Daejeon, Korea).

\subsection{Extraction, Fractionation, and Isolation}

The dried EGFOB (2.9 kg) were extracted twice with 70\% aqueous ethanol (30 L each time) by using an electric extractor (COSMOS-660, Kyungseo Machine Co., Incheon, Korea) at $80 \pm 2{ }^{\circ} \mathrm{C}$ for $3 \mathrm{~h}$. The extract solution was filtered, concentrated using a rotary evaporator system (EYELA N-12, Rikakikai Co., Tokyo, Japan) under vacuum, and freeze-dried to obtain a powdered extract (179.3 g, $6.2 \%)$. This powdered extract $(165.0 \mathrm{~g})$ was suspended in water $(1 \mathrm{~L})$ and successively partitioned four times with $1 \mathrm{~L}$ each of $n$-hexane, EtOAc, and $n$-BuOH to obtain $n$-hexane (7.3 g), EtOAc (16.3 g), and $n$-BuOH (28.6 g)-soluble fractions. The EtOAc-soluble fraction (15.5 g), which significantly inhibited A $\beta$ aggregation, was subjected to silica gel column chromatography $(70-230$ mesh, $11 \times 19 \mathrm{~cm})$ and eluted with a stepwise gradient of $\mathrm{CH}_{2} \mathrm{Cl}_{2}-\mathrm{MeOH}(100: 1,80: 1,40: 1,20: 1,10: 1,5: 1,3: 1,2: 1,1: 1$, and $0: 1)$ to afford six fractions (F1-F6). F1 (960.0 mg) was subjected to ODS column chromatography $\left(\mathrm{S}-75 \mu \mathrm{m}, 2.3 \times 40 \mathrm{~cm}\right.$ ) and eluted with an $\mathrm{MeOH}-\mathrm{H}_{2} \mathrm{O}$ gradient $(60: 40 \rightarrow 100: 0)$ to obtain ten fractions (F1-1-F1-10). F1-8 (79.0 mg) was further purified using preparative HPLC with a Luna $\mathrm{C}_{18}$ column $(21.2 \times 250 \mathrm{~mm}, 5 \mu \mathrm{m})$ containing $\mathrm{ACN}-\mathrm{H}_{2} \mathrm{O}(94: 6)$ to obtain compound 16 (12.4 mg). F2 (746.0 mg) was chromatographed on the ODS column $(2.3 \times 40 \mathrm{~cm})$ and eluted with an $\mathrm{MeOH}-\mathrm{H}_{2} \mathrm{O}$ gradient $(40: 60 \rightarrow 100: 0)$ to obtain nine fractions (F2-1-F2-9). F2-4 (65.7 mg) was subjected to preparative HPLC $\left(21.2 \times 250 \mathrm{~mm}, 5 \mu \mathrm{m}\right.$, Luna $\left.\mathrm{C}_{18}\right)$ with $\mathrm{ACN}-\mathrm{H}_{2} \mathrm{O}(45: 55)$ as the eluent and then recrystallized to obtain compound $10(3.8 \mathrm{mg})$. Compound $15(28.3 \mathrm{mg})$ was isolated from F2-8 (117.0 $\mathrm{mg})$ by preparative HPLC $\left(21.2 \times 250 \mathrm{~mm}, 5 \mu \mathrm{m}\right.$, Luna $\left.\mathrm{C}_{18}\right)$ with $\mathrm{ACN}-\mathrm{H}_{2} \mathrm{O}(88: 12)$ as the eluent. F3 (5.1 g) was chromatographed on an ODS column $(4 \times 49 \mathrm{~cm})$ and eluted with an $\mathrm{MeOH}-\mathrm{H}_{2} \mathrm{O}$ gradient $(10: 90 \rightarrow 100: 0)$ to obtain twenty-four fractions (F3-1-F3-24). Compound 1 (10.0 mg) was isolated from F3-1 (90.0 mg) through 
silica gel column $(2.3 \times 42 \mathrm{~cm})$ chromatography involving a $\mathrm{CH}_{2} \mathrm{Cl}_{2}-\mathrm{MeOH}$ gradient $(10: 1 \rightarrow 1: 1)$ as the eluent. F3-5 (1.3 g) was subjected to silica gel column $(3 \times 45 \mathrm{~cm})$ chromatography and eluted with a $\mathrm{CH}_{2} \mathrm{Cl}_{2}-\mathrm{MeOH}$ gradient $(40: 1 \rightarrow 1: 1)$ to obtain compound 4 (250.0 mg). Subfraction F3-5-6 (217.0 mg) was further purified using preparative HPLC $\left(20 \times 250 \mathrm{~mm}, 5 \mu \mathrm{m}\right.$, Triart $\left.\mathrm{C}_{18}\right)$ with $\mathrm{ACN}-\mathrm{H}_{2} \mathrm{O}(13: 87)$ as the eluent to obtain compounds $7(39.5 \mathrm{mg})$ and $9(27.0 \mathrm{mg})$. F3-6 (226.0 $\mathrm{mg})$ was chromatographed on a silica gel column $(2.3 \times 32 \mathrm{~cm})$ by eluting with a $\mathrm{CH}_{2} \mathrm{Cl}_{2}-\mathrm{MeOH}$ gradient $(40: 1 \rightarrow 1: 1)$ and further purified using preparative HPLC $\left(20 \times 250 \mathrm{~mm}, 5 \mu \mathrm{m}\right.$, Triart $\left.\mathrm{C}_{18}\right)$ with $\mathrm{ACN}-\mathrm{H}_{2} \mathrm{O}(8: 92)$ as the eluent to obtain compound $3(4.6 \mathrm{mg})$. F3-7 (534.0 $\mathrm{mg})$ was subjected to consecutive preparative HPLC $\left(20 \times 250 \mathrm{~mm}, 5 \mu \mathrm{m}\right.$, Triart $\left.\mathrm{C}_{18}\right)$ to obtain compound 5 (68.0 mg). Compounds 11 (18.0 mg) and 12 (30.0 mg) were isolated from F3-15 (100.0 mg) and F3-17 (178.0 mg), respectively, by using preparative HPLC $\left(10 \times 250 \mathrm{~mm}, 5 \mu \mathrm{m}\right.$, Luna $\left.\mathrm{C}_{18}\right)$ with $\mathrm{ACN}-\mathrm{H}_{2} \mathrm{O}(19: 81)$ as the eluent, followed by recrystallization. Compound $14(13.5 \mathrm{mg})$ was purified from F3-24 (70.0 $\mathrm{mg})$ by using preparative HPLC $\left(21.2 \times 250 \mathrm{~mm}, 5 \mu \mathrm{m}\right.$, Luna $\left.\mathrm{C}_{18}\right)$ with an $\mathrm{ACN}-\mathrm{H}_{2} \mathrm{O}$ gradient $(83: 17 \rightarrow 84: 16)$ as the eluent. F4 (4.4 g) was applied on a Sephadex LH-20 column $(4.2 \times 50 \mathrm{~cm})$ and eluted with an $\mathrm{MeOH}-\mathrm{H}_{2} \mathrm{O}$ gradient $(10: 90 \rightarrow 100: 0)$ to obtain ten fractions (F4-1-F4-10). Compound $2(20.0 \mathrm{mg})$ was isolated from F4-2 (72.0 mg) by using preparative HPLC $\left(21.2 \times 250 \mathrm{~mm}, 5 \mu \mathrm{m}\right.$, Luna $\left.\mathrm{C}_{18}\right)$ with $\mathrm{ACN}-\mathrm{H}_{2} \mathrm{O}$ (2:98) as the eluent. F4-5 (285.5 mg) was chromatographed on a silica gel column $(2.2 \times 50 \mathrm{~cm})$ with a $\mathrm{CH}_{2} \mathrm{Cl}_{2}-\mathrm{MeOH}$ gradient $(40: 1 \rightarrow 1: 1)$ as the eluent and subsequently purified through preparative HPLC $\left(21.2 \times 250 \mathrm{~mm}, 5 \mu \mathrm{m}\right.$, Luna $\left.\mathrm{C}_{18}, \mathrm{ACN}-\mathrm{H}_{2} \mathrm{O}(6: 94)\right)$ to obtain compound 6 (7.0 mg). F4-6 (1.4 g) was subjected to silica gel column $(3.2 \times 40 \mathrm{~cm})$ chromatography involving a $\mathrm{CH}_{2} \mathrm{Cl}_{2}-\mathrm{MeOH}$ gradient $(40: 1 \rightarrow 1: 1)$ as the eluent and purified through consecutive preparative HPLC $(21.2 \times 250 \mathrm{~mm}, 5 \mu \mathrm{m}$, Luna $\left.\mathrm{C}_{18}\right)$ to obtain compound $\mathbf{8}(13.5 \mathrm{mg})$. Compound 13 (3.6 mg) was isolated from F4-9 (262.0 mg) through consecutive preparative $\mathrm{HPLC}\left(21.2 \times 250 \mathrm{~mm}, 5 \mu \mathrm{m}\right.$, Luna $\left.\mathrm{C}_{18}\right)$ with $\mathrm{ACN}-\mathrm{H}_{2} \mathrm{O}(27: 73)$ and $\mathrm{ACN}-\mathrm{H}_{2} \mathrm{O}(24: 76)$ as the eluents.

\subsection{A $\beta$ Aggregation Assay}

To measure the inhibitory effect on $A \beta_{1-42}$ aggregation, the SensoLyte ${ }^{\circledR}$ Thioflavin $T$ (ThT) $\beta$-Amyloid aggregation kit (AnaSpec, Fremont, CA, USA) was used according to the modified manufacturer's instructions. This assay is based on the property of ThT dye that increases fluorescence when bound to the aggregates of $A \beta_{1-42}$ peptides. The detailed protocol is described in a previous report [53]. Morin $(100 \mu \mathrm{M})$ was used as a positive control for the inhibition of $A \beta$ aggregation. Experiments were performed in triplicate and independently repeated three times. The inhibition rate (\%) of $A \beta$ aggregation was calculated according to the following equation:

$$
\text { Inhibition of } \mathrm{A} \beta \text { aggregation }(\%)=\left(1-\frac{\text { Fluorescence of } \mathrm{A} \beta-\text { treated sample }}{\text { Fluorescence of untreated sample }}\right) \times 100
$$

\subsection{Free Radical Scavenging Assay}

ABTS and DPPH radical scavenging assays were performed with reference to the modified method described in previously published reports [54,55] to examine the antioxidant activities. In the ABTS assay, $7 \mathrm{mM}$ ABTS aqueous solution and $2.45 \mathrm{mM}$ potassium persulfate were reacted for $12-16$ $\mathrm{h}$ in the dark at room temperature to prepare the $\mathrm{ABTS}^{\bullet+}$ solution. Subsequently, the reactant was diluted 25-fold to adjust its absorbance at $734 \mathrm{~nm}$ to 0.7 by using a spectrophotometer (Benchmark Plus, Bio-Rad, Hercules, CA). The sample solution $(100 \mu \mathrm{L})$ and ABTS ${ }^{\bullet+}$ solution $(100 \mu \mathrm{L})$ were mixed and incubated for $5 \mathrm{~min}$ at room temperature in the dark.

To determine the DPPH radical scavenging activity, the sample solution $(100 \mu \mathrm{L})$ and $0.15 \mathrm{mM}$ DPPH solution $(100 \mu \mathrm{L})$ were mixed and incubated for $3 \mathrm{~h}$ at room temperature in the dark. 
The absorbance was measured at $517 \mathrm{~nm}$. Ascorbic acid was used as a positive control for antioxidative activity. The radical scavenging activity (\%) was calculated using the following equation:

$$
\text { Radical scavenging activity }(\%)=\left(1-\frac{\text { Absorbance of sample }}{\text { Absorbance of control }}\right) \times 100
$$

\subsection{Statistical Analysis}

Calculated values were expressed as mean \pm SEM. One-way analysis of variance or Student's $t$-test was performed using GraphPad Prism 7.0 (GraphPad Software, San Diego, CA, USA) to determine statistical significance. $P$-values $<0.05$ were considered statistically significant.

\section{Conclusions}

Our data demonstrate that the ethanol extract of EGFOB has anti-A $\beta$ aggregation and antioxidant activities. Sixteen compounds (1-16) were isolated from the ethanol extract of EGFOB by using chromatographic techniques. The chemical structures of these compounds were determined using 1D and 2D NMR spectroscopy, or electrospray ionization mass spectrometry. Among these sixteen compounds, compounds 8, 9, and 13 showed potent antioxidative and anti-A $\beta$ aggregation activities. These results suggest that EGFOB, especially compounds procyanidin B3 (8), procyanidin B4 (9), and helichrysoside (13), may be promising candidate therapeutics against $\mathrm{AD}$ and $\mathrm{AD}$-related diseases.

Supplementary Materials: The NMR spectra (Figures S1-S33), spectroscopic and physicochemical data of compounds 1-16 are available online.

Author Contributions: Conceptualization, Y.J.K. and S.-J.J.; methodology, Y.J.K. and S.-J.J.; formal analysis, Y.J.K. and E.S.; investigation, Y.J.K., E.S., M.N., and S.-J.J.; resources, J.-H.K.; data curation, Y.J.K.; writing—original draft preparation, Y.J.K.; writing-review and editing, S.-J.J.; project administration, S.-J.J.; funding acquisition, S.-J.J. All authors have read and agreed to the published version of the manuscript.

Funding: This research was funded by Korea Institute of Oriental Medicine, grant numbers KSN1515293 and KSN2013240.

Acknowledgments: We thank Jin Sook Kim (Korea Institute of Oriental Medicine) and the Korean Seed Association for their kind donation of the plant specimens.

Conflicts of Interest: The authors declare no conflict of interest.

\section{References}

1. Sahoo, A.K.; Dandapat, J.; Dash, U.C.; Kanhar, S. Features and outcomes of drugs for combination therapy as multi-targets strategy to combat Alzheimer's disease. J. Ethnopharmacol. 2018, 215, 42-73. [CrossRef]

2. Alzheimer's Association. 2018 Alzheimer's Disease facts and figures. Alzheimers Dement. 2018, 14, $367-429$. [CrossRef]

3. Lane, C.A.; Hardy, J.; Schott, J.M. Alzheimer's disease. Eur. J. Neur. 2018, 25, 59-70. [CrossRef]

4. Barage, S.H.; Sonawane, K.D. Amyloid cascade hypothesis: Pathogenesis and therapeutic strategies in Alzheimer's disease. Neuropeptides 2015, 52, 1-18. [CrossRef]

5. Burns, A.; Jacoby, R.; Levy, R. Psychiatric phenomena in Alzheimer's disease. I: Disorders of thought content. Br. J. Psychiatry 1990, 157, 72-76. [CrossRef]

6. Brothers, H.M.; Gosztyla, M.L.; Robinson, S.R. The physiological roles of amyloid- $\beta$ peptide hint at new ways to treat Alzheimer's disease. Front. Aging Neurosci. 2018, 10, 118. [CrossRef] [PubMed]

7. Gomes, L.M.F.; Mahammed, A.; Prosser, K.E.; Smith, J.R.; Silverman, M.A.; Walsby, C.J.; Gross, Z.; Storr, T. A catalytic antioxidant for limiting amyloid-beta peptide aggregation and reactive oxygen species generation. Chem. Sci. 2018, 10, 1634-1643. [CrossRef] [PubMed]

8. Li, H.M.; Yu, S.P.; Fan, T.Y.; Zhong, Y.; Gu, T.; Wu, W.Y.; Zhao, C.; Chen, Z.; Chen, M.; Li, N.G.; et al. Design, synthesis, and biological activity evaluation of BACE1 inhibitors with antioxidant activity. Drug Dev. Res. 2020, 81, 206-214. [CrossRef] [PubMed]

9. Peña-Bautista, C.; Baquero, M.; Vento, M.; Cháfer-Pericás, C. Free radicals in Alzheimer's disease: Lipid peroxidation biomarkers. Clin. Chim. Acta 2019, 491, 85-90. [CrossRef] [PubMed] 
10. Kawahara, M.; Ohtsuka, I.; Yokoyama, S.; Kato-Negishi, M.; Sadakane, Y. Membrane incorporation, channel formation and disruption of calcium homeostasis by Alzheimer's $\beta$-amyloid protein. Int. J. Alzheimers Dis. 2011, 2011, 304583.

11. Huang, W.J.; Zhang, X.; Chen, W.W. Role of oxidative stress in Alzheimer's disease. Biomed. Rep. 2016, 4, 519-522. [CrossRef] [PubMed]

12. Atri, A. Effective Pharmacological Management of Alzheimer's Disease. Am. J. Manag. Care 2011, 17, S346-S355.

13. Harvey, A.L. Natural products in drug discovery. Drug Discov. Today 2008, 13, 894-901. [CrossRef] [PubMed]

14. Yuan, H.; Ma, Q.; Ye, L.; Piao, G. The traditional medicine and modern medicine from natural products. Molecules 2016, 21, 559. [CrossRef]

15. National Institute of Biological Resources. National Biodiversity Database. Available online: http://species. nibr.go.kr (accessed on 10 June 2020).

16. Li, L.H.; Baek, I.K.; Kim, J.H.; Kang, K.H.; Koh, Y.S.; Jung, Y.D.; Cho, C.K.; Choi, S.Y.; Shin, B.A. Methanol extract of Elaeagnus glabra, a Korean medicinal plant, inhibits HT1080 tumor cell invasion. Oncol. Rep. 2009, 21, 559-563.

17. Nishino, C.; Enoki, N.; Tawata, S.; Mori, A.; Kobayashi, K.; Fukushima, M. Antibacterial activity of flavonoids against Staphylococcus epidermidis, a skin bacterium. Agric. Biol. Chem. 1987, 51, 139-143. [CrossRef]

18. Ahmadiani, A.; Hosseiny, J.; Semnanian, S.; Javan, M.; Saeedi, F.; Kamalinejad, M.; Saremi, S. Antinociceptive and anti-inflammatory effects of Elaeagnus angustifolia fruit extract. J. Ethnopharmacol. 2000, 72, 287-292. [CrossRef]

19. Okmen, G.; Turkcan, O. A Study on antimicrobial, antioxidant and antimutagenic activities of Elaeagnus angustifolia, L. leaves. Afr. J. Tradit. Complement. Altern. Med. 2013, 11, 116-120. [CrossRef]

20. Nazir, N.; Zahoor, M.; Nisar, M.; Khan, I.; Karim, N.; Abdel-Halim, H.; Ali, A. Phytochemical analysis and antidiabetic potential of Elaeagnus umbellata (Thunb.) in streptozotocin-induced diabetic rats: Pharmacological and computational approach. BMC Complement. Altern. Med. 2018, 18, 332. [CrossRef]

21. Wang, S.Y.; Bowman, L.; Ding, M. Variations in free radical scavenging capacity and antiproliferative activity among different genotypes of autumn olive (Elaeagnus umbellata). Planta Med. 2007, 73, 468-477. [CrossRef]

22. Sohn, E.; Lim, H.-S.; Kim, Y.J.; Kim, B.-Y.; Kim, J.-H.; Jeong, S.-J. Elaeagnus glabra f. oxyphylla attenuates scopolamine-induced learning and memory impairments in mice by improving cholinergic transmission via activation of CREB/NGF signaling. Nutrients 2019, 11, 1205. [CrossRef] [PubMed]

23. Han, J.; Chen, X.; Liu, W.; Cui, H.; Yuan, T. Triterpenoid saponin and lignan glycosides from the traditional medicine Elaeagnus angustifolia flowers and their cytotoxic activities. Molecules 2020, 25, 462. [CrossRef] [PubMed]

24. Teich, A.F.; Arancio, O. Is the Amyloid Hypothesis of Alzheimer's disease therapeutically relevant? Biochem. J. 2012, 446, 165-177. [CrossRef] [PubMed]

25. Lim, H.-S.; Kim, Y.J.; Sohn, E.; Yoon, J.; Kim, B.-Y.; Jeong, S.-J. Annona atemoya leaf extract ameliorates cognitive impairment in amyloid- $\beta$ injected Alzheimer's disease-like mouse model. Exp. Biol. Med. 2019, 244, 1665-1679. [CrossRef]

26. Shin, S.J.; Jeong, Y.O.; Jeon, S.G.; Kim, S.; Lee, S.K.; Nam, Y.; Park, Y.H.; Kim, D.; Lee, Y.S.; Choi, H.S.; et al. Jowiseungchungtang inhibits Amyloid- $\beta$ aggregation and amyloid- $\beta$-mediated pathology in 5XFAD mice. Int. J. Mol. Sci. 2018, 19, 4026. [CrossRef]

27. Lim, S.; Choi, J.G.; Moon, M.; Kim, H.G.; Lee, W.; Bak, H.R.; Sung, H.; Park, C.H.; Kim, S.Y.; Oh, M.S. An optimized combination of ginger and peony root effectively inhibits amyloid- $\beta$ accumulation and amyloid- $\beta$-mediated pathology in A $\beta$ PP/PS1 double-transgenic mice. J. Alzheimers Dis. 2016, 50, 189-200. [CrossRef]

28. Jack, C.R.; Knopman, D.S.; Jagust, W.J.; Petersen, R.C.; Weiner, M.W.; Aisen, P.S.; Shaw, L.M.; Vemuri, P.; Wiste, H.J.; Weigand, S.D.; et al. Tracking pathophysiological processes in Alzheimer's disease: An updated hypothetical model of dynamic biomarkers. Lancet Neurol. 2013, 12, 207-216. [CrossRef]

29. Rhimi, W.; Hlel, R.; Ben Salem, I.; Boulila, A.; Rejeb, A.; Saidi, M. Dittrichia viscosa L. ethanolic extract based ointment with antiradical, antioxidant, and healing wound activities. Biomed. Res. Int. 2019, 2019, 4081253. [CrossRef]

30. Ullah, F.; Iqbal, N.; Ayaz, M.; Sadiq, A.; Ullah, I.; Ahmad, S.; Imran, M. DPPH, ABTS free radical scavenging, antibacterial and phytochemical evaluation of crude methanolic extract and subsequent fractions of Chenopodium botrys aerial parts. Pak. J. Pharm. Sci. 2017, 30, 761-766. 
31. Mayes, J.; Tinker-Mill, C.; Kolosov, O.; Zhang, H.; Tabner, B.J.; Allsop, D. $\beta$-amyloid fibrils in Alzheimer disease are not inert when bound to copper ions but can degrade hydrogen peroxide and generate reactive oxygen species. J. Biol. Chem. 2014, 289, 12052-12062. [CrossRef]

32. Chen, K.; Kazachkov, M.; Yu, P.H. Effect of aldehydes derived from oxidative deamination and oxidative stress on beta-amyloid aggregation; pathological implications to Alzheimer's disease. J. Neural. Transm. 2007, 114, 835-839. [CrossRef]

33. Yoon, K.D.; Rho, T. Chemical constituents of Nelumbo nucifera seeds. Nat. Prod. Sci. 2017, 23, $253-257$.

34. Abdullah, N.H.; Salim, F.; Ahmad, R. Chemical constituents of malaysian U. cordata var. ferruginea and their in vitro $\alpha$-glucosidase inhibitory activities. Molecules 2016, 21, 525. [CrossRef]

35. Chang, S.W.; Kim, K.H.; Lee, I.K.; Choi, S.U.; Ryu, S.Y.; Lee, K.R. Phytochemical Constituents of Bistorta manshuriensis. Nat. Prod. Sci. 2009, 15, 234-240.

36. Zor, M.; Aydin, S.; Güner, N.D.; Başaran, N.; Başaran, A.A. Antigenotoxic properties of Paliurus spinachristi Mill fruits and their active compounds. BMC Complement. Altern. Med. 2017, 17, 229. [CrossRef]

37. Usman, A.; Thoss, V.; Nur-e-Alam, M. Isolation of (-)-Epicatechin from Trichilia emetica Whole Seeds. Am. J. Org. Chem. 2016, 6, 81-85.

38. Liao, C.R.; Kuo, Y.H.; Ho, Y.L.; Wang, C.Y.; Yang, C.S.; Lin, C.W.; Chang, Y.S. Studies on cytotoxic constituents from the leaves of Elaeagnus oldhamii Maxim. in non-small cell lung cancer A549 cells. Molecules 2014, 19, 9515. [CrossRef]

39. Wang, C.M.; Hsu, Y.M.; Jhan, Y.L.; Tsai, S.J.; Lin, S.X.; Su, C.H.; Chou, C.H. Structure elucidation of procyanidins isolated from Rhododendron formosanum and their anti-oxidative and anti-bacterial activities. Molecules 2015, 20, 12787. [CrossRef]

40. Taniguchi, S.; Kuroda, K.; Yoshikado, N.; Doi, K.; Tanabe, M.; Shibata, T.; Yoshida, T.; Hatano, T. New dimeric flavans from gambir, an extract of Uncaria gambir. Heterocycles 2007, 74, 595-605.

41. Yuan, H.; Lu, X.; Ma, Q.; Li, D.; Xu, G.; Piao, G. Flavonoids from Artemisia sacrorum Ledeb. and their cytotoxic activities against human cancer cell lines. Exp. Ther. Med. 2016, 12, 1873-1878. [CrossRef] [PubMed]

42. Ren, G.; Hou, J.; Fang, Q.; Sun, H.; Liu, X.; Zhang, L.; Wang, P.G. Synthesis of flavonol 3-O-glycoside by UGT78D1. Glycoconj. J. 2012, 29, 425-432. [CrossRef]

43. Wan, C.; Yuan, T.; Cirello, A.L.; Seeram, N.P. Antioxidant and $\alpha$-glucosidase inhibitory phenolics isolated from highbush blueberry flowers. Food Chem. 2012, 135, 1929-1937. [CrossRef] [PubMed]

44. Amoussa, A.M.; Lagnika, L.; Bourjot, M.; Vonthron-Senecheau, C.; Sanni, A. Triterpenoids from Acacia ataxacantha DC: Antimicrobial and antioxidant activities. BMC Complement. Altern. Med. 2016, 16, 284. [CrossRef]

45. Jeong, W.; Hong, S.S.; Kim, N.; Yang, Y.T.; Shin, Y.S.; Lee, C.; Hwang, B.Y.; Lee, D. Bioactive triterpenoids from Callistemon lanceolatus. Arch. Pharm. Res. 2009, 32, 845-849. [CrossRef]

46. Kawanishi, K.; Hashimoto, Y. Long chain esters of Virola species. Phytochemistry 1987, 26, 749-752. [CrossRef]

47. Farzaei, M.H.; Bahramsoltani, R.; Abbasabadi, Z.; Rahimi, R. A comprehensive review on phytochemical and pharmacological aspects of Elaeagnus angustifolia L. J. Pharm. Pharmacol. 2015, 67, 1467-1480. [CrossRef] [PubMed]

48. Zhu, J.X.; Wen, L.; Zhong, W.J.; Xiong, L.; Liang, J.; Wang, H.L. Quercetin, Kaempferol and Isorhamnetin in Elaeagnus pungens Thunb. Leaf: Pharmacological Activities and Quantitative Determination Studies. Chem. Biodivers. 2018, 15, e1800129. [CrossRef] [PubMed]

49. Mori, Y.; Kato, S.; Fujisawa, Y.; Ohnishi, S.; Hiraku, Y.; Kawanishi, S.; Murata, M.; Oikawa, S. Mechanisms of DNA damage induced by morin, an inhibitor of amyloid $\beta$-peptide aggregation. Free Radic. Res. 2019, 53, 115-123. [CrossRef]

50. Andarzi Gargari, S.; Barzegar, A.; Tarinejad, A. The role of phenolic OH groups of flavonoid compounds with $\mathrm{H}$-bond formation ability to suppress amyloid mature fibrils by destabilizing $\beta$-sheet conformation of monomeric Aß17-42. PLoS ONE 2018, 13, e0199541. [CrossRef]

51. Sato, M.; Murakami, K.; Uno, M.; Nakagawa, Y.; Katayama, S.; Akagi, K.; Masuda, Y.; Takegoshi, K.; Irie, K. Site-specific inhibitory mechanism for amyloid $\beta 42$ aggregation by catechol-type flavonoids targeting the Lys residues. J. Biol. Chem. 2013, 288, 23212-23224. [CrossRef] [PubMed]

52. Matos, A.M.; Cristóvão, J.S.; Yashunsky, D.V.; Nifantiev, N.E.; Viana, A.S.; Gomes, C.M.; Rauter, A.P. Synthesis and effects of flavonoid structure variation on amyloid- $\beta$ aggregation. Pure Appl. Chem. 2017, 89, 1305-1320. [CrossRef] 
53. Kim, Y.J.; Lim, H.-S.; Kim, J.-H.; Na, M.; Jeong, S.-J. Quantitative analysis of 7 compounds in Diospyros lotus leaf extract and its biological effects on neuroprotection and antineuroinflammation. Nat. Prod. Commun. 2020, 15, 1-12.

54. Re, R.; Pellegrini, N.; Proteggente, A.; Pannala, A.; Yang, M.; Rice-Evans, C. Antioxidant activity applying an improved ABTS radical cation decolorization assay. Free Radic. Bio. Med. 1999, 26, 1231-1237. [CrossRef]

55. Moreno, M.I.; Isla, M.I.; Sampietro, A.R.; Vattuone, M.A. Comparison of the free radical-scavenging activity of propolis from several regions of Argentina. J. Ethnopharmacol. 2000, 71, 109-114. [CrossRef]

Sample Availability: Samples of the compounds are available from the authors.

Publisher's Note: MDPI stays neutral with regard to jurisdictional claims in published maps and institutional affiliations.

(C) 2020 by the authors. Licensee MDPI, Basel, Switzerland. This article is an open access article distributed under the terms and conditions of the Creative Commons Attribution (CC BY) license (http://creativecommons.org/licenses/by/4.0/). 